Available online on 15.09.2021 at http://jddtonline.info
Open Access to Pharmaceutical and Medical Research
$\begin{aligned} & \text { Copyright } \text { ( 2021 The Author(s): This is an open-access article distributed under the terms of the CC BY-NC } 4.0 \\ & \text { which permits unrestricted use, distribution, and reproduction in any medium for non } \text {-commercial use provided } \\ & \text { the original author and source are credited }\end{aligned}$
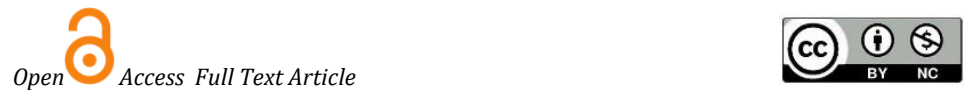

Research Article

\title{
Physicochemical, Druggable, ADMET Pharmacoinformatics and Therapeutic Potentials of Azadirachtin - a Prenol Lipid (Triterpenoid) from Seed Oil Extracts of Azadirachta indica A. Juss.
}

\author{
T. Loganathan ${ }^{1}$, A. Barathinivas ${ }^{2}$, C. Soorya ${ }^{3}$, S. Balamurugan 4 , T. G. Nagajothi' ${ }^{5}$, S. Ramya ${ }^{3}$, R. Jayakumararaj ${ }^{3 *}$ \\ ${ }^{1}$ Department of Plant Biology and Plant Biotechnology, LN Government College (Autonomous), Ponneri - 601204, TN, India \\ ${ }^{2}$ Department of Zoology, Yadava College for Men, Tirupalai- 625 017, Madurai, TamilNadu, India \\ ${ }^{3}$ Department of Botany, Government Arts College, Melur - 625106, Madurai, TamilNadu, India \\ ${ }^{4}$ Department of Mathematics, Government Arts College, Melur - 625106, Madurai, TamilNadu, India \\ ${ }^{5}$ Department of Botany, R D Government Arts College, Sivagangai - 630561, TamilNadu, India
}

\section{Article Info:}

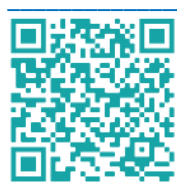

\section{Article History:}

Received 06 July 2021 Reviewed 09 August 2021 Accepted 16 August 2021 Published 15 Sep 2021

\section{Cite this article as: \\ Loganathan T, Barathinivas A, Soorya C, Balamurugan S, Nagajothi TG, Ramya S, Jayakumararaj R, Physicochemical, Druggable, ADMET Pharmacoinformatics and Therapeutic Potentials of Azadirachtin - a Prenol Lipid (Triterpenoid) from Seed Oil Extracts of Azadirachta indica A. Juss., Journal of Drug Delivery and Therapeutics. 2021; 11(5):33-46}

DOI: http://dx.doi.org/10.22270/jddt.v11i5.4981

\section{*Address for Correspondence:}

R. Jayakumararaj, Department of Plant Biology and Plant Biotechnology, LN Government College (Autonomous), Ponneri - 601204, TN, India

\section{Abstract}

Azadirachtin (AZA) is the most abundant bioactive secondary metabolite (BASM) in neem seed oil extract (NSOE) of Azadirachta indica A. Juss. AZA is localised in different parts of the plant (seeds, fruits, flowers, leaves, stem, bark and root) however, with varying degree of concentration. It has been documented that maximum concentration of AZA is present to the tune of $48000 \mu \mathrm{g} \mathrm{g}^{-1}$ in the seeds. It has been established that the environmental conditions determines the overall content and composition of BASM in different parts of the plant. Neem plant parts are most commonly used as therapeutic agents in remote villages in India for its ethnomedicinal therapeutic potentials; however, its physicochemical, druggable and pharmacological properties inadequately described. In the present study an attempt has been made to evaluate the physicochemical, druggable and pharmacological properties of Azadirachtin in NSOE of $A$. indica from ADMET perspectives.

Keywords: NEEM; Azadirachta indica; Azadirachtin; Pharmacoinformatics; ADMET; DrugLikeness; Toxicology

\section{INTRODUCTION}

Azadirachta indica A. Juss commonly known as Neem or Margosa belongs to the family Meliaceae ${ }^{1-3}$. Popular as Miracle tree it is a natural store-house of phyto-drugs since the dawn of civilization 4,5 . This tree is one of the most versatile plant across the country and elsewhere known for its use in various Indigenous/ Traditional Systems of Medicine. A. indica has its origin from India and is commonly distributed in the South East Asian (SEA) Region (Bangladesh, Srilanka, Bhutan, Myanmar, Pakistan, and Nepal) ${ }^{6}$, however, it has been disseminated world over, in particular the tropical and sub-tropical regions ${ }^{7}$.

Neem is a perennial, small to medium-sized (10 - $15 \mathrm{~m})$ and fast-growing tree and grows well in locations with temperature to a maximum of $48-50{ }^{\circ} \mathrm{C}$, the plant needs low annual rainfall (400 - $800 \mathrm{~mm} /$ annum). Furthermore, the plant grows well in poor/ degraded/ mined soils. However, growth is affected by low temperature (poor growth below $14^{\circ} \mathrm{C}$ ) and frosts. Being the storehouse/ repository of wide array of BASM, Neem tree remains the ideal target of interest for research. As most of the BASM are localised in the leaves and seeds, destruction of whole plant is not required for the isolation/ extraction of bioactive principles. Furthermore, being perennial, annual replenishment of leaves and seeds prevents whole-plant harvest. BASM of Neem contains high proportion of water-soluble substances that favours DIY extraction and application in folklore medicine. Moreover, majority of these metabolites are eco-friendly bioactive compounds that are biodegradable in nature, adhere to GRAS standards, therefore harmless to man and environment ${ }^{8}$.

$A$. indica shows therapeutics potential in healthcare and management due to rich source of BASM $^{9-11}$. The most important active constituent is azadirachtin, while others 
include nimbolinin, nimbin, nimbidin, nimbidol, sodium nimbinate, gedunin, salannin, and quercetin. Leaves contain BASM such as nimbin, nimbanene, 6-desacetylnimbinene, nimbandiol, nimbolide, ascorbic acid, n-hexacosanol, 7desacetyl-7-benzoylazadiradione,

7-desacetyl-7benzoylgedunin, 17-hydroxyazadiradione, and nimbiol ${ }^{12-14}$ Quercetin and $\beta$-sitosterol, polyphenolic flavonoids, obtained from fresh leaves have significant antibacterial and antifungal properties; while seeds are comparably rich in azadirachtin ${ }^{14}$.

Since antiquity all parts of the plant, including root, stem, bark, leaves, fruits, and seeds are used to cure various ailments in humans and domestic animals therefore, Neem has been considered as a multi-purposes village dispensary ${ }^{15-25}$. In fact, therapeutic applications attributed to Neem include abortive, analgesic, antibacterial, anticancer, antidiabetic, antifungal, anti-helminthic, anti-hyperglycemic, anti-inflammatory, antimalarial, antipyretic, antispasmodic, anti-spermatogenic, antiviral, diuretic, hyper-cholesteremic, immuno-modulatory, mouth-wash, contraception, dental plaque, head lice, heart disease, insect repellent, malaria, pesticide, psoriasis, skin diseases, wound healing, gastrointestinal ailments $26-55$.

Neem is influenced by a myriad of factors, namely geographic area, climate, genetic variability, agronomic conditions, plant morphology and physiology, collection and storage of plant material which determines the therapeutic potential. Further, this variation affects the development processes as regulation of secondary metabolite synthesis is directly linked to gene expression. This boils down to the fact that growth of Neem plant and the biochemical composition of the active principle is significantly influenced by external parameters. Kaushik et $\mathrm{al}^{56}$. and Tomar et $\mathrm{al}^{57}$. independently, analysed trees from different regions of India and observed significant difference in the AZA content of seeds collected in different regions. Furthermore, Kaushik et

\section{MATERIALS AND METHODS}

Class

\section{Subclass}

Superorder

Order

Family

Genus

Species

Common Name

Vernacular Name
: Equisetopsida C. Agardh

: Magnoliidae Novák Ex Takht.

: Rosanae Takht.

: Sapindales Juss. Ex Bercht.

: Meliaceae Juss.

: Azadirachta A. Juss.

: Azadirachta indica A. Juss.

: Neem

: Vempu (Tamil) al56. evaluated the effect of climatic conditions in the AZA content of seeds and indicated that AZA values of samples from semi-arid regions with mild winters were different from values observed in hot sub-humid, hot arid and hot semi-arid with cold winter regions. Similarly, Zheng et al.58 pointed out that season and ecosystem properties significantly affect neem seed oil yield and, in a less extent, AZA content. In fact, AZA quantity obtained in seed was significantly influenced by precipitation, with lower values observed in rainy season. Likewise, the procedure and time of collection of the plant material also influences AZA concentration in the seeds. In the case of seeds, AZA concentration is maximized when clean and healthy seeds are collected 59,60 .

Indeed, it has been reported that mechanical damage, insect infestation and fungal infection of seeds significantly affect quantity and quality of AZA content. Since its isolation for the first time in 1968, AZA has been the subject of intense research, particularly of biological, synthetic and structural studies $^{61}$. Azadirachtin - limonoid group of compound is a bioactive secondary metabolite present in neem seeds $12,13,26,27,60$. It is a highly oxidized tetranortriterpenoid that asserts a plethora of oxygen-bearing functional group which includes an enol-ether, acetal, hemiacetal, tetrasubstituted epoxide structure with variety of carboxylic esters (Fig. 1). Increasing interest in AZA is mainly due to the unique biomolecular properties, including broad spectrum of activity even in trace amounts, no or low toxicity to mammals. Its complex structure makes its synthesis a daunting task. Biological activities attributed to AZA include application as a bioinsecticide, biopesticide, insect-pest repellent as it is non-toxicity to humans. Azadirachtin has been identified as potential inhibitor of SARS-CoV-2 main protease ${ }^{62-64}$ and is expected to play a major role in the management of COVID-19. Furthermore, pharmacological characterization is expected to validate Azadirachtin as novel drug lead $65-68$.

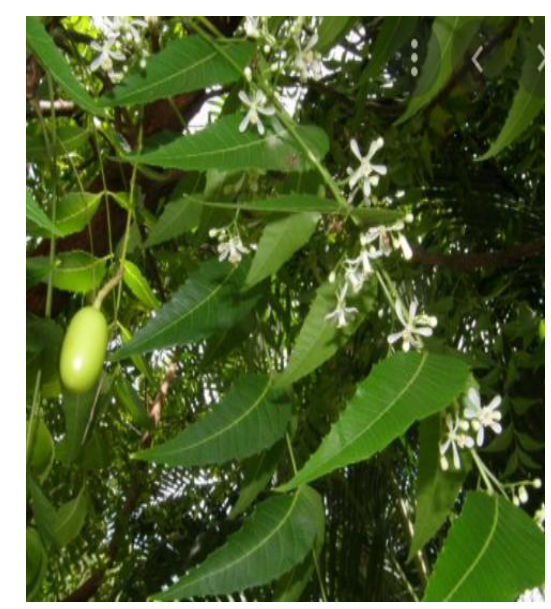

$2.0 \mathrm{~cm}$ long, greenish-yellow, Seed: 1-seeded. Plants were collected from the fields in the wild Palani Hills, Western Ghats, INDIA as described previously33.

glabrous; Leaves imparipinnate, pulvinus at the base; leaflets alternate to opposite, $2.5-7.0 \mathrm{~cm}$ long, $1.5-4.0 \mathrm{~cm}$ broad, ovate, subsessile, acuminate; Flowers white, sweet-scented; Sepals obovate, $1.5 \mathrm{~mm}$ long, puberulous, imbricate. Petals 6 $\mathrm{mm}$ long, obvoate to oblong, white, margin ciliate; Staminal tube $5 \mathrm{~mm}$ long, puberulous, 10 -striate, 10 -toothed; teeth 2lobed; anthers oblong, basifixed; Ovary sub-globose; style linear $2.5 \mathrm{~mm}$ long; stigma trifid. Fruit: Drupe oblong, 1.3 -

\section{GC-MS Analysis}

Neem Seed Oil Extracts of $A$. indica was obtained from the seed samples collected from the foothills of Alagar Hills, Alagarkovil Reserve Forest, Dindigul District, Tamil Nadu, India. Phyto-components were identified using GC-MS 
detection system as described previously, however with modification, whereby portion of the extract was analysed directly by headspace sampling. GC-MS analysis was accomplished using an Agilent 7890A GC system set up with 5975C VL MSD (Agilent Technologies, CA, USA). Capillary column used was DB-5MS $(30 \times 0.25 \mathrm{~mm}$, film thickness of $0.25 \mu \mathrm{m}$; J\&W Scientific, CA, USA). Temperature program was set as follows: initial temperature $50^{\circ} \mathrm{C}$ held for $1 \mathrm{~min}$, $5^{\circ} \mathrm{C}$ per min to $100^{\circ} \mathrm{C}, 9^{\circ} \mathrm{C}$ per min to $200^{\circ} \mathrm{C}$ held for 7.89 $\mathrm{min}$, and the total run time was $40 \mathrm{~min}$. The flow rate of helium as a carrier gas was $0.811851 \mathrm{~mL} / \mathrm{min}$. MS system was performed in electron ionization (EI) mode with Selected Ion Monitoring (SIM). The ion source temperature and quadruple temperature were set at $230^{\circ} \mathrm{C}$ and $150^{\circ} \mathrm{C}$, respectively. Identification of phyto-components was performed by comparison of their retention times and mass with those of authentic standards spectra using computer searches in NIST 08.L and Wiley 7n.l libraries 3,33 .

\section{ADMET Prediction}

PubChem database was applied to get the smiles structures of the natural compounds, and was further used for the ADMET prediction. The qualitative assessment of pharmacokinetics viz; absorption, distribution, metabolism, excretion and toxicity (ADMET) profile of selected compounds were predicted computationally by using SwissADME and toxicity prediction using TOPKAT (Accelrys, Inc., USA). QikProp develops and employs QSAR/QSPR models using partial least squares, principal component analysis and multiple linear regression to predict physicochemical significant descriptors ${ }^{68-70}$.

\section{RESULTS AND DISCUSSION}

\section{Chemical kingdom}

Super class

Class

Subclass

PubChem Identifier

Synonyms

Canonical SMILES

InChI Key

\section{Organic compounds}

: $\quad$ Lipids and lipid-like molecules

: $\quad$ Prenol lipids

: Triterpenoids

: $\mathbf{1 0 2 1 4 6 5 8 6}$

: Azadirachtanin

: $\quad$ CC(=0)0[C@@H]10C[C@@]23C([C@@]1(C)[C@H](OC(=0)C)C[C@@H]20)C[C@H] $([C @] 1([C @ H] 3 C(=0)[C @ H](O C=0) C)[C @] 2(C 1=C C[C @ H] 2 c 1 c c o c 1) C) C) 0$
Physicochemical Properties: The molecular weight of AZA was $720.72(\mathrm{~g} / \mathrm{mol})$; the calculated $\log P$ value was -0.20 ; LogD - 0.14; LogSw - -4.34. The total number of stereocenters in the molecule was 16; the stereo-chemical complexity of the molecule was 0.457 ; the calculated Fsp3 value of AZA was 0.771; The overall calculated Topological polar surface area of AZA was 215.34(Å2). Likewise the calculated number of hydrogen bond donors in the molecule was 3 ; whereas the number of hydrogen bond acceptors was 16; the number of smallest set of smallest rings (SSSR) in the molecule analyzed was 2 ; the size of the biggest system ring in the molecule was 15; similarly, the total number of rotatable bonds in the molecule was 6 ; the number of rigid bonds was 38; the number of charged groups was 0; similarly the total charge of the compound was 0 ; the number of carbon atoms in the molecule was 35; whereas the number of heteroatoms in AZA was calculated as 16; the number of heavy atoms in the molecule was calculated as 51; the ratio between the number of non-carbon atoms and the number of carbon atoms in the compound was 0.46 (Fig. 2,3).

Druggability Properties: Lipinski's rule of 5 violations of the molecule was 2; Veber rule was Low for the molecule; similarly Egan rule for the molecule was also Low; the Oral PhysChem score (Traffic Lights) for the molecule was recorded as 5; GSK's 4/400 score for the molecule was Good; Pfizer's 3/75 score for the molecule was Good; Weighted quantitative estimate of drug-likeness (QEDw) score for the molecule was 0.164; Solubility Forecast Index was Good and the solubility score was 9441.49 ;

ADMET Properties: Only when the ADME/Tox properties of a drug like compound are of high quality, and when the target has been validated, the compound could be developed into a pharma-drug. In silico drug-likeness evaluation of Azadirachtin for Human Intestinal Absorption (HIA+) value had a probability of 0.890; Blood Brain Barrier (BBB-) value for the molecule had a probability of 0.773; Caco-2 permeable (Caco2-) value for the molecule had a probability of 0.711 (Fig. 4); P-glycoprotein substrate (Substrate) value for the molecule had a probability of 0.835 ; P-glycoprotein inhibitor I (Inhibitor) value for the molecule had a probability of 0.672; P-glycoprotein inhibitor II (Noninhibitor) value for the molecule had a probability of 0.534 . CYP450 2C9 substrate (Non-substrate) value for the molecule had a probability of 0.857 ; CYP450 2D6 substrate (Non-substrate) - 0.872; CYP450 3A4 substrate (Substrate) 0.714; CYP450 1A2 inhibitor (Non-inhibitor) - 0.887; CYP450 2C9 inhibitor (Non-inhibitor) - 0.845; CYP450 2D6 inhibitor (Non-inhibitor) - 0.944; CYP450 2C19 inhibitor (Noninhibitor) - 0.833; CYP450 3A4 inhibitor (Non-inhibitor) 0.770; CYP450 inhibitory promiscuity (Low CYP Inhibitory Promiscuity) - 0.886; Ames test (Non AMES toxic) - 0.756; Carcinogenicity (Non-carcinogens) - 0.946; Biodegradation (Not ready biodegradable) - 1.000; Rat acute toxicity (4.348 LD50, mol/kg) - PNA; hERG inhibition (predictor I) (Weak inhibitor) - 0.992; hERG inhibition (predictor II) (Noninhibitor) - 0.569 respectively. Computational methods for analysing and estimating the toxicity of natural bioactive compounds are considered as useful tool for validation as it provides in-depth understanding of toxicogenomics. Therefore, determining the toxicity of BASM in-silico is warranted to identify their potential harmful effects on humans, animals, plants, besides the environment as in-vivo animal tests are constrained by time, ethical considerations, and financial burden. Data pertaining to the descriptors viz., Toxicity, Environmental toxicity, Tox21 pathway and Toxicophore Rules for Azadirachtin are summarized in Table 
2. Furthermore, GPCR ligand, ion channel modulator, kinase inhibitor, nuclear receptor ligand, protease inhibitor, enzyme inhibitor score for AZA were calculated as $-0.71 ;-1.51 ;-1.46$; $-0.67 ;-0.35$ and -0.71 respectively (Fig. 3). Swiss Target Prediction towards Macrophage migration inhibitory factor, Heat shock protein (HSP 90-alpha), Kappa Opioid receptor, $\mathrm{Mu}$ opioid receptor, Delta opioid receptor, Thrombin, Squalene synthetase, Glycogen synthase kinase-3 beta, Glycogen synthase kinase- 3 alpha, Protein kinase $\mathrm{C}$ alpha, Apoptosis regulator Bcl-X, HMG-CoA reductase, Zinc finger protein GLI1, Proto-oncogene c-JUN, Vanilloid receptor for the compound has been provided in Table 4. Chemical and biological investigations on Azadirachta indica bioactive compounds indicates that the compound is safe for use as a drug molecule $3,72,72$.

\section{CONCLUSION}

The present study is an example to insights into the broad scope of pharmacoinformatics to plant based natural product research with an emphasis on drug discovery. The study indicates that plant based natural products still possess an extraordinary challenge that has to be solved before taken for drug development. However, it is anticipated that as more quality data on natural product research, such as bioactivity, biomolecularinformatics, cheminformatics, toxicoinformatics integrated together with new algorithms and machine learning techniques to accelerate natural product based drug discovery. Furthermore, online databases serve as attractive sources for identifying novel natural product scaffolds with promising drug-like properties in NPs which is expected to accelerate the pace of Drug Discovery.

\section{REFERENCES}

1. Kalaivani T, Meignanam E, Premkumar N, Siva R, Vijayakumar V, Rajasekaran C, Ramya S, Jayakumararaj R. Studies on hepatoprotective properties of leaf extracts of Azadirachta indica A. Juss (Meliaceae). Ethnobotanical Leaflets 2009; 2009(1):20.

2. Schmutterer H, Ascher KR. Neem tree (Azadirachta indica A. Juss.) and other meliaceous plants VCH; 1995 https://doi.org/10.1002/3527603980

3. Loganathan T, Barathinivas A, Soorya C, Balamurugan S, Nagajothi TG, Ramya S, \& Jayakumararaj R GCMS Profile of Bioactive Secondary Metabolites with Therapeutic Potential in the Ethanolic Leaf Extracts of Azadirachta indica - A Sacred Traditional Medicinal Plant of INDIA Journal of Drug Delivery and Therapeutics. 2021 (IN-PRESS)

4. Zeenat F, Ravish MS, Ahmad W, Ahmad I. Therapeutic, phytochemistry and pharmacology of Azadirachta indica: A review. Int J Unani Integr Med. 2018; 2(1):20-8.

5. Biswas K, Chattopadhyay I, Banerjee RK, Bandyopadhyay U. Biological activities and medicinal properties of neem (Azadirachta indica). Current Science. 2002:1336-45.

6. Negi PS, Jayaprakasha GK, Jena BS. Distribution and introduction cultivation state of Azadirachta indica Food Chemistry. 2002; 80:293-7.

7. Yan_ping ZH, Yong_qi LA, Xing_ming PE, Juan LI. Global Distribution and Introduction Cultivation State of Azadirachta indica [J]. Forest Inventory and Planning. 2002; 3(2)5-9.

8. Ramya S, \& Jayakumararaj R. Antifeedant activity of selected ethno-botanicals used by tribals of Vattal Hills on Helicoverpa armigera (Hübner). Journal of Pharmacy Research. 2009; 2(8):1414-1418.

9. Islas JF, Acosta E, Zuca G, Delgado-Gallegos JL, Moreno-Treviño MG, Escalante B, Moreno-Cuevas JE. An overview of Neem Azadirachta indica and its potential impact on health. Journal of
Functional Foods. 2020; 74:104171.

https://doi.org/10.1016/j.jff.2020.104171

10. Rahmani A, Almatroudi A, Alrumaihi F, Khan A. Pharmacological and therapeutic potential of neem (Azadirachta indica). Pharmacognosy Reviews. 2018; 12(24).

https://doi.org/10.4103/phrev.phrev_8_18

11. Bhowmik D, Chiranjib YJ, Tripathi KK, Kumar KS. Herbal remedies of Azadirachta indica and its medicinal application. J Chem Pharm Res. 2010; 2(1):62-72.

12. Chen J, Fan X, Zhu J, Song L, Li Z, Lin F, Yu R, Xu H, Zi J. Limonoids from seeds of Azadirachta indica A. Juss. and their cytotoxic activity. Acta pharmaceutica sinica B. 2018; 8(4):639-44. https://doi.org/10.1016/j.apsb.2017.12.009

13. Khanal $P$, Magadum $P$, Patil BM, Hullatti KK. In silico docking study of Limonoids from Azadirachta indica with pfpk5: A Novel Target for Plasmodium falciparum. Indian Journal of Pharmaceutical Sciences. 2019; 81(2):326-32. https://doi.org/10.36468/pharmaceutical-sciences.514

14. Kraus W, Cramer R, Sawitzki G. Tetranortriterpenoids from the seeds of Azadirachta indica Phytochemistry. 1981; 20(1):11720. https://doi.org/10.1016/0031-9422(81)85229-6

15. Willy S, Nilan R, Kekare MB, Vikas V. Estimation of two bioactive compounds from Azadirachta indica A. Juss. leaves using HPLC. International Journal of Pharma and Bio Sciences. 2010; 1(2).

16. Mitra CR, Garg HS, Pandey GN. Identification of nimbidic acid and nimbidinin from Azadirachta indica Phytochemistry. 1971; 10(4):857-64. https://doi.org/10.1016/S0031-9422(00)971565

17. Moga MA, Bălan A, Anastasiu CV, Dimienescu OG, Neculoiu CD, Gavriș C. An overview on the anticancer activity of Azadirachta indica (Neem) in gynecological cancers. International journal of molecular sciences. 2018; 19(12):3898. https://doi.org/10.3390/ijms19123898

18. Baildya N, Khan AA, Ghosh NN, Dutta T, Chattopadhyay AP. Screening of potential drug from Azadirachta indica (Neem) extracts for SARS-CoV-2: an insight from molecular docking and MD-simulation studies. Journal of Molecular Structure 2021; 1227:129390 https://doi.org/10.1016/j.molstruc.2020.129390

19. Eid A, Jaradat N, Elmarzugi N. A Review of chemical constituents and traditional usage of Neem plant (Azadirachta indica). Palestinian Medical and Pharmaceutical Journal. 2017; 2(2):7581.

20. Hossain MA, Al-Toubi WA, Weli AM, Al-Riyami QA, Al-Sabahi JN Identification and characterization of chemical compounds in different crude extracts from leaves of Omani neem. Journal of Taibah University for Science. 2013; 7(4):181-8. https://doi.org/10.1016/j.jtusci.2013.05.003

21. Kumar R, Sharma S, Devi L. Investigation of total phenolic, flavonoid contents and antioxidant activity from extracts of Azadirachta indica of Bundelkhand Region. Int. J. Life. Sci. Scienti. Res. eISSN. 2018; 2455(1716):1716. https://doi.org/10.21276/ijlssr.2018.4.4.10

22. Siddiqui BS, Afshan F, Faizi S, Naqvi SN, Tariq RM. Two insecticidal tetranortriterpenoids from Azadirachta indica Phytochemistry. 2000; 53(3):371-6. https://doi.org/10.1016/S0031-9422(99)00548-8

23. Awolu 00, Obafaye RO, Ayodele BS. Optimization of solvent extraction of oil from neem Azadirachta indica and its characterizations. Journal of Scientific Research and Reports. 2013; 10:304-314 https://doi.org/10.9734/JSRR/2013/3705

24. Agrawal S, Popli DB, Sircar K, Chowdhry A. A review of the anticancer activity of Azadirachta indica (Neem) in oral cancer. Journal of Oral Biology and Craniofacial Research. 2020 Apr 1; 10(2):206-9. https://doi.org/10.1016/j.jobcr.2020.04.007

25. Agrawal S, Popli DB, Sircar K, Chowdhry A. A review of the anticancer activity of Azadirachta indica (Neem) in oral cancer. 
Journal of Oral Biology and Craniofacial Research. 2020 Apr 1; 10(2):206-9. https://doi.org/10.1016/j.jobcr.2020.04.007

26. Upadhyay SN, Dhawan S, Garg S, Talwar GP. Immunomodulatory effects of neem Azadirachta indica oil. International Journal of Immunopharmacology. 1992; 14(7):1187-93. https://doi.org/10.1016/0192-0561(92)90054-0

27. Muhammad A, Kashere MA. NEEM, Azadirachta indica L.(A. Juss): an eco-friendly botanical insecticide for managing farmers 'insects pest problems - a review. FUDMA Journal of Sciences. 2020; 4(4):484-91. https://doi.org/10.33003/fjs-2020-0404506

28. Benelli G, Canale A, Toniolo C, Higuchi A, Murugan K, Pavela R, Nicoletti M. Neem (Azadirachta indica): towards the ideal insecticide?. Natural product research. 2017; 31(4):369-86. https://doi.org/10.1080/14786419.2016.1214834

29. Schmutterer H. Properties and potential of natural pesticides from the neem tree, Azadirachta indica Annual review of entomology. 1990; 35(1):271-97.

https://doi.org/10.1146/annurev.en.35.010190.001415

30. Gupta SC, Prasad S, Tyagi AK, Kunnumakkara AB, Aggarwal BB. Neem (Azadirachta indica): An Indian traditional panacea with modern molecular basis. Phytomedicine. 2017; 34:14-20. https://doi.org/10.1016/j.phymed.2017.07.001

31. Hashmat I, Azad H, Ahmed A. Neem (Azadirachta indica A. Juss) A nature's drugstore: an overview. Int Res J Biol Sci. 2012; 1(6):76-9.

32. Ramya S, Neethirajan K \& Jayakumararaj R. Profile of bioactive compounds in Syzygium cumini-a review. J. Pharm. Res 2012; 5(8):4548-4553.

33. Soorya C, Balamurugan S, Basha AN, Kandeepan C, Ramya S, Jayakumararaj R. Profile of Bioactive Phyto-compounds in Essential Oil of Cymbopogon martinii from Palani Hills, Western Ghats, INDIA. Journal of Drug Delivery and Therapeutics. 2021; 11(4):60-5. https://doi.org/10.22270/jddt.v11i4.4887

34. Saleem S, Muhammad G, Hussain MA, Bukhari SN. A comprehensive review of phytochemical profile, bioactives for pharmaceuticals, and pharmacological attributes of Azadirachta indica Phytotherapy research. 2018; 32(7):1241-72. https://doi.org/10.1002/ptr.6076

35. Sarkar S, Singh RP, Bhattacharya G. Exploring the role of Azadirachta indica (neem) and its active compounds in the regulation of biological pathways: an update on molecular approach. 3 Biotech. 2021; 11(4):1-2. https://doi.org/10.1007/s13205-021-02745-4

36. Ahmad S, Maqbool A, Srivastava A, Gogol S. Biological detail and therapeutic effect of Azadirachta indica (neem tree) products-a review. J. Evidence Based Med. Healthcare. 2019; 6(22):16071612. https://doi.org/10.18410/jebmh/2019/324

37. Alzohairy MA. Therapeutics role of Azadirachta indica (Neem) and their active constituents in diseases prevention and treatment Evidence-Based Complementary and Alternative Medicine. 2016; 2016 https://doi.org/10.1155/2016/7382506

38. Venugopal V. Antidermatophytic activity of neem Azadirachta indica leaves in vitro. Indian Journal of Pharmacology. 1994; 26(2):141.

39. Tembe-Fokunang EA, Charles F, Kaba N, Donatien G, Michael A, Bonaventure $\mathrm{N}$. The potential pharmacological and medicinal properties of neem (Azadirachta indica A. Juss) in the drug development of phytomedicine Journal of Complementary and Alternative Medical Research. 2019; 23:1-8 https://doi.org/10.9734/jocamr/2019/v7i130093

40. Srivastava SK, Agrawal B, Kumar A, Pandey A. Phytochemicals of Azadirachta indica source of active medicinal constituent used for cure of various diseases: A Review. Journal of Scientific Research. 2020; 64(1):385-90.

https://doi.org/10.37398/JSR.2020.640153
41. Krist S. Neem Oil. InVegetable Fats and Oils 2020 (pp. 467-473). Springer, Cham. https://doi.org/10.1007/978-3-030-303143_75

42. Jain S, Ganeshpurkar A, Dubey N. Molecular Docking of some Neem Constituents with COX-2 and NOs: An in silico Study. Pharmacognosy Communications. 2020 Jul 1; 10(3):134-5. https://doi.org/10.5530/pc.2020.3.26

43. Rajasekaran C, Meignanam E, Vijayakumar V, Kalaivani T, Ramya $\mathrm{S}$, Premkumar N, Siva R, Jayakumararaj R Investigations on antibacterial activity of leaf extracts of Azadirachta indica A. Juss (Meliaceae): a traditional medicinal plant of India. Ethnobotanical Leaflets. 2008; 2008(1):161-.167

44. Roy S, Bhattacharyya P. Possible role of traditional medicinal plant Neem Azadirachta indica for the management of COVID-19 infection. Int. J. Res. Pharm. Sci. 2020:122-5. https://doi.org/10.26452/ijrps.v11iSPL1.2256

45. Patel SM, Venkata KC, Bhattacharyya P, Sethi G, Bishayee A. Potential of neem (Azadirachta indica L.) for prevention and treatment of oncologic diseases. In Seminars in cancer biology 2016; 40:100-115. Academic Press.

https://doi.org/10.1016/j.semcancer.2016.03.002

46. Paul R, Prasad M, Sah NK. Anticancer biology of Azadirachta indica L (neem): a mini review. Cancer biology \& therapy. 2011; 12(6):467-76. https://doi.org/10.4161/cbt.12.6.16850

47. Lloyd AC, Menon T, Umamaheshwari K. Anticandidal activity of Azadirachta indica Indian Journal of Pharmacology. 2005; 37(6):386. https://doi.org/10.4103/0253-7613.19076

48. Waheed A., Miana G.A., Ahmad S.I. Clinical investigation of hypoglycemic effect of seeds of Azadirachta indica in type 2 (NIDDM) diabetes mellitus. Pak. J. Pharm. Sci. 2006; 19:322-325.

49. Khan MR, Chonhenchob V, Huang C, Suwanamornlert P. Antifungal Activity of Propyl Disulfide from Neem (Azadirachta indica) in Vapor and Agar Diffusion Assays against Anthracnose Pathogens (Colletotrichum gloeosporioides and Colletotrichum acutatum) in Mango Fruit. Microorganisms. 2021 Apr; 9(4):839. https://doi.org/10.3390/microorganisms9040839

50. Afolabi OJ, Simon-Oke IA, Oladokun OI. Antiplasmodial Activity of Ethanolic Extract of Neem Leaf (Azadirachta indica) in Albino Mice Infected with Plasmodium berghei. Int Arch Clin Pharmacol. 2021; 7:024. https://doi.org/10.23937/25723987.1510024

51. Dharshini AD, Muralidharan NP. Neem as antiviral agents. International Journal of Pharmaceutical Research. 2020 Jan 1; 12. https://doi.org/10.31838/ijpr/2020.SP1.017

52. Patil SM, Shirahatti PS, Ramu R, Prasad N. Azadirachta indica A. Juss (neem) as a contraceptive: An evidence-based review on its pharmacological efficiency. Phytomedicine. 2021; 19:153596. https://doi.org/10.1016/j.phymed.2021.153596

53. Kalaivani T, Meignanam E, Premkumar N, Siva R, Vijayakumar V, Rajasekaran C, Ramya S, Jayakumararaj R. Studies on hepatoprotective properties of leaf extracts of Azadirachta indica A. Juss (Meliaceae). Ethnobotanical Leaflets 2009; 2009(1):20.

54. Isdadiyanto S, Sitasiwi AJ, Mardiati SM. The lipid profile of rats (Rattus norvegicus L.) induced by high fat ration after exposed to ethanolic neem (Azadirazchta indica) leaf extract. Journal of Physics: Conference Series 2020 Apr 1 (Vol. 1524, No. 1, p. 012126). IOP Publishing. https://doi.org/10.1088/17426596/1524/1/012126

55. Dwivedi VD, Bharadwaj S, Afroz S, Khan N, Ansari MA, Yadava U, Tripathi RC, Tripathi IP, Mishra SK, Kang SG. Anti-dengue infectivity evaluation of bioflavonoid from Azadirachta indica by dengue virus serine protease inhibition. Journal of Biomolecular Structure and Dynamics. 2021; 39(4):1417-30. https://doi.org/10.1080/07391102.2020.1734485

56. Kaushik N, Singh BG, Tomar UK, Naik SN, Vir S, Bisla SS, Sharma KK, Banerjee SK, Thakkar P. Regional and habitat variability in 
azadirachtin content of Indian neem (Azadirachta indica A. Juss). Current Science. 2007:1400-1406.

57. Tomar UK, Singh G, Kaushik N. Screening Azadirachta indica tree for enhancing azadirachtin and oil contents in dry areas of Gujarat, India. Journal of Forestry Research. 2011; 22(2):217-24. https://doi.org/10.1007/s11676-011-0153-0

58. Zheng Y, Wu J, Wang Y, Peng X, Zhang Y. Seed yield and azadirachtin content of Azadirachta indica in four ecosystems of southwest China. Industrial Crops and Products. 2018; 122:2327. https://doi.org/10.1016/j.indcrop.2018.05.040

59. Gahukar RT. Factors affecting content and bioefficacy of neem (Azadirachta indica A. Juss.) phytochemicals used in agricultural pest control: a review. Crop Protection. 2014; 62:93-99. https://doi.org/10.1016/j.cropro.2014.04.014

60. Singh B, Pandya D, Mankad A. A Review on Different Pharmacological \& Biological Activities of Azadirachta indica A. Juss and Melia azedarach L. The Journal of Plant Science Research 2020; 36(1/2):57-63.

61. Veitch GE, Boyer A, Ley SV. The azadirachtin story. Angewandte Chemie International Edition. 2008; 47(49):9402-29. https://doi.org/10.1002/anie.200802675

62. Borkotoky S, Banerjee M. A computational prediction of SARS CoV-2 structural protein inhibitors from Azadirachta indica (Neem). Journal of Biomolecular Structure and Dynamics. 2020; 8:1-1. https://doi.org/10.1080/07391102.2020.1774419

63. Muhammed D, Odey BO, Alozieuwa BU, Alawode RA, Okunlola BM, Ibrahim J, Lawal A, Berinyuy EB. Azadirachtin-A a bioactive compound from Azadirachta indica is a potential inhibitor of SARS-CoV-2 main protease. AROC in Pharmaceutical and Biotechnology. 2021; 1(1):1-8. https://doi.org/10.53858/arocpb01010108

64. Fernandes SR, Barreiros L, Oliveira RF, Cruz A, Prudêncio C, Oliveira AI, Pinho C, Santos N, Morgado J. Chemistry, bioactivities, extraction and analysis of azadirachtin: State-ofthe-art. Fitoterapia. 2019; 134:141-50.

https://doi.org/10.1016/j.fitote.2019.02.006
65. Adegbola PI, Semire B, Fadahunsi OS, Adegoke AE Molecular docking and ADMET studies of Allium cepa, Azadirachta indica and Xylopia aethiopica isolates as potential anti-viral drugs for Covid-19. Virus Disease. 2021; 32(1):85-97. https://doi.org/10.1007/s13337-021-00682-7

66. Durán-Iturbide NA, Díaz-Eufracio BI, Medina-Franco JL. In silico ADME/Tox profiling of natural products: A focus on BIOFACQUIM. ACS omega. 2020; 5(26):16076-84. https://doi.org/10.1021/acsomega.0c01581

67. Medina-Franco JL, Saldívar-González FI. Cheminformatics to characterize pharmacologically active natural products. Biomolecules. 2020; 10(11):1566. https://doi.org/10.3390/biom10111566

68. Soorya C, Balamurugan S, Ramya S, Neethirajan K, Kandeepan C, \& Jayakumararaj R. Physicochemical, ADMET and Druggable properties of Myricetin: A Key Flavonoid in Syzygium cumini that regulates metabolic inflammations. Journal of Drug Delivery and Therapeutics, $2021 ; 11(4): 66-3$. https://doi.org/10.22270/jddt.v11i4.4890

69. Gleeson M P. Generation of a set of simple, interpretable ADMET rules of thumb J Med Chem, 2008, 51(4):817-34. https://doi.org/10.1021/jm701122q

70. Xiong G, Wu Z, Yi J, Fu L, Yang Z, Hsieh C, Yin M, Zeng X, Wu C, Lu A, Chen X. ADMETlab 2.0: an integrated online platform for accurate and comprehensive predictions of ADMET properties. Nucleic Acids Research. 2021 Apr 24. https://doi.org/10.1093/nar/gkab255

71. Govindachari TR. Chemical and biological investigations on Azadirachta indica (the neem tree). Current science. 1992; 63(3):117-22.

72. Lakshmi T, Krishnan V, Rajendran R, Madhusudhanan N. Azadirachta indica: A herbal panacea in dentistry-An update. Pharmacognosy reviews. 2015; 9(17):41. https://doi.org/10.4103/0973-7847.156337

Table 1 Physicochemical, Medicinal Chemistry and ADMET properties of AZA

\section{Physicochemical Property}

\begin{tabular}{|c|c|c|}
\hline Property & Value & Comment \\
\hline Molecular Weight & 720.26 & Contain hydrogen atoms. Optimal:100 600 \\
\hline Volume & 670.289 & Van der Waals volume \\
\hline Density & 1.075 & Density = MW / Volume \\
\hline nHA & 16 & Number of hydrogen bond acceptors. Optimal:0 12 \\
\hline nHD & 3 & Number of hydrogen bond donors. Optimal:0 7 \\
\hline nRot & 10 & Number of rotatable bonds. Optimal:0 11 \\
\hline nRing & 8 & Number of rings. Optimal:0 6 \\
\hline MaxRing & 14 & Number of atoms i The biggest ring. Optimal:0 18 \\
\hline nHet & 16 & Number of heteroatoms. Optimal:1 15 \\
\hline fChar & 0 & Formal charge. Optimal:- $4 \sim 4$ \\
\hline nRig & 38 & Number of rigid bonds. Optimal:0 30 \\
\hline Flexibility & 0.263 & Flexibility $=$ nRot $/ \mathrm{nRig}$ \\
\hline Stereo Centers & 16 & Optimal: $£ 2$ \\
\hline TPSA & 215.34 & Topological Polar Surface Area. Optimal:0 140 \\
\hline $\log S$ & -3.837 & Log of the aqueous solubility. Optimal: $-4 \sim 0.5 \log \mathrm{mol} / \mathrm{L}$ \\
\hline
\end{tabular}




\begin{tabular}{|c|c|c|}
\hline $\log P$ & 1.306 & Log of the octanol/water partition coefficient. Optimal: $0 \sim 3$ \\
\hline $\log D$ & 1.493 & $\log \mathrm{P}$ at physiological pH 7.4. Optimal: $1 \sim 3$ \\
\hline \multicolumn{3}{|c|}{ 2. Medicinal Chemistry } \\
\hline Property & Value & Comment \\
\hline QED & 0.14 & $\begin{array}{l}\text { A measure of drug-likeness based o The concept of desirability; Attractive: }>0.67 \text {; } \\
\text { unattractive: } 0.49 \sim 0.67 \text {; too complex: }<0.34\end{array}$ \\
\hline SAscore & 7.579 & $\begin{array}{l}\text { Synthetic accessibility score is designed to estimate ease of synthesis of drug-like } \\
\text { molecules. } n \text { SAscore }{ }^{3} 6 \text {, difficult to synthesize; SAscore }<6 \text {, easy to synthesize }\end{array}$ \\
\hline Fsp3 & 0.771 & $\begin{array}{l}\text { The number of sp3 hybridized carbons / total carbon count, correlating with melting } \\
\text { point and solubility. } \mathrm{n} \text { Fsp } 3^{3} 0.42 \text { is considered a suitable value. }\end{array}$ \\
\hline MCE-18 & 215.065 & $\begin{array}{l}\text { MCE-18 stands for medicinal chemistry evolution. n MCE-18 } 345 \text { is considered a } \\
\text { suitable value. }\end{array}$ \\
\hline NPscore & 3.457 & $\begin{array}{l}\text { Natural product-likeness score. } \mathrm{n} \text { This score is typically i The range from }-5 \text { to } 5 \text {. The } \\
\text { higher the score is, the higher the probability is that the molecule is a NP. }\end{array}$ \\
\hline Lipinski Rule & Rejected & $\begin{array}{l}\text { MW } £ 500 \text {; } \log P £ 5 ; \text { Hacc } £ 10 \text {; Hdon } £ 5 \mathrm{n} \text { If two properties are out of range, a poor } \\
\text { absorption or permeability is possible, one is acceptable. }\end{array}$ \\
\hline Pfizer Rule & Accepted & $\begin{array}{l}\log \mathrm{P}>3 ; \mathrm{TPSA}<75 \text { Compounds with a high } \log \mathrm{P}(>3) \text { and low TPSA }(<75) \text { are likely } \\
\text { to be toxic. }\end{array}$ \\
\hline GSK Rule & Rejected & $\begin{array}{l}\text { MW } £ 400 \text {; } \log P £ 4 \mathrm{n} \text { Compounds satisfying the GSK rule may have a more favourable } \\
\text { ADMET profile }\end{array}$ \\
\hline Golden Triangle & Rejected & $\begin{array}{l}200 £ \text { MW } £ 50 ;-2 £ \log D £ 5 \mathrm{n} \text { Compounds satisfying the Golden Triangle rule may } \\
\text { have a more favourable ADMET profile. }\end{array}$ \\
\hline PAINS & 0 alerts & $\begin{array}{l}\text { Pan Assay Interference Compounds, frequent hitters, Alpha-screen artifacts and } \\
\text { reactive compound. }\end{array}$ \\
\hline ALARM NMR & 1 alerts & Thiol reactive compounds. \\
\hline BMS & 0 alerts & Undesirable, reactive compounds. \\
\hline Chelator Rule & 0 alerts & Chelating compounds. \\
\hline \multicolumn{3}{|l|}{ 3. Absorption } \\
\hline Property & Value & Comment \\
\hline $\begin{array}{l}\text { Caco-2 } \\
\text { Permeability }\end{array}$ & -5.261 & Optimal: higher than -5.15 Log unit \\
\hline MDCK Permeability & 0.000138 & $\begin{array}{l}\text { low permeability: }<2 \times 10-6 \mathrm{~cm} / \mathrm{s} \mathrm{n} \text { medium permeability: } 2-20 \times 10-6 \mathrm{~cm} / \mathrm{s} \mathrm{n} \text { high } \\
\text { passive permeability: }>20 \times 10-6 \mathrm{~cm} / \mathrm{s}\end{array}$ \\
\hline Pgp-inhibitor & 1 & $\begin{array}{l}\text { Category 1: Inhibitor; Category 0: Non-inhibitor; The output value is the probability of } \\
\text { being Pgp-inhibitor }\end{array}$ \\
\hline Pgp-substrate & 0.975 & $\begin{array}{l}\text { Category 1: substrate; Category 0: Non-substrate; The output value is the probability } \\
\text { of being Pgp-substrate }\end{array}$ \\
\hline HIA & 0.66 & $\begin{array}{l}\text { Human Intestinal Absorption Category 1: HIA }+(\text { HIA }<30 \%) \text {; Category 0: HIA- }- \text { HIA }< \\
30 \%) \text {; The output value is the probability of being HIA }+\end{array}$ \\
\hline F20\% & 0.649 & $\begin{array}{l}\text { 20\% Bioavailability Category 1: F20\%+ (bioavailability <20\%); Category 0: F20\%- } \\
\text { (bioavailability }{ }^{3} 20 \% \text { ); The output value is the probability of being F20\%+ }\end{array}$ \\
\hline F30\% & 0.985 & $\begin{array}{l}30 \% \text { Bioavailability Category 1: F30\%+ (bioavailability <30\%); Category 0: F30\%- } \\
\text { (bioavailability }{ }^{3} 30 \% \text { ); The output value is the probability of being F30\%+ }\end{array}$ \\
\hline \multicolumn{3}{|l|}{ 4. Distribution } \\
\hline Property & Value & Comment \\
\hline PPB & $38.52 \%$ & $\begin{array}{l}\text { Plasma Protein Binding n Optimal: }<90 \% \text {. Drugs with high protein-bound may have a } \\
\text { low therapeutic index. }\end{array}$ \\
\hline VD & 1.581 & Volume Distribution n Optimal: 0.04-20L/kg \\
\hline
\end{tabular}




\begin{tabular}{|c|c|c|c|}
\hline BBB Penetration & \multicolumn{2}{|c|}{0.246} & $\begin{array}{l}\text { Blood-Brain Barrier Penetration Category 1: BBB+; Category 0: BBB-; The output } \\
\text { value is the probability of being BBB+ }\end{array}$ \\
\hline Fu & \multicolumn{2}{|c|}{$37.25 \%$} & The fraction unbound in plasms n Low: $<5 \%$; Middle: 5 20\%; High: $>20 \%$ \\
\hline \multicolumn{4}{|l|}{ 5. Metabolism } \\
\hline Property & Value & \multicolumn{2}{|c|}{ Comment } \\
\hline $\begin{array}{l}\text { CYP1A2 } \\
\text { inhibitor }\end{array}$ & 0 & \multicolumn{2}{|c|}{$\begin{array}{l}\text { Category 1: Inhibitor; Category 0: Non-inhibitor; } \\
\text { The output value is the probability of being inhibitor. }\end{array}$} \\
\hline $\begin{array}{l}\text { CYP1A2 } \\
\text { substrate }\end{array}$ & 0.993 & \multicolumn{2}{|c|}{$\begin{array}{l}\text { Category 1: Substrate; Category 0: Non-substrate; } \\
\text { The output value is the probability of being substrate. }\end{array}$} \\
\hline $\begin{array}{l}\text { CYP2C19 } \\
\text { inhibitor }\end{array}$ & 0.017 & \multicolumn{2}{|c|}{$\begin{array}{l}\text { Category 1: Inhibitor; Category 0: Non-inhibitor; } \\
\text { The output value is the probability of being inhibitor. }\end{array}$} \\
\hline $\begin{array}{l}\text { CYP2C19 } \\
\text { substrate }\end{array}$ & 0.724 & \multicolumn{2}{|c|}{$\begin{array}{l}\text { Category 1: Substrate; Category 0: Non-substrate; } \\
\text { The output value is the probability of being substrate. }\end{array}$} \\
\hline $\begin{array}{l}\text { CYP2C9 } \\
\text { inhibitor }\end{array}$ & 0.014 & \multicolumn{2}{|c|}{$\begin{array}{l}\text { Category 1: Inhibitor; Category 0: Non-inhibitor; } \\
\text { The output value is the probability of being inhibitor. }\end{array}$} \\
\hline $\begin{array}{l}\text { CYP2C9 } \\
\text { substrate }\end{array}$ & 0.005 & \multicolumn{2}{|c|}{$\begin{array}{l}\text { Category 1: Substrate; Category 0: Non-substrate; } \\
\text { The output value is the probability of being substrate. }\end{array}$} \\
\hline $\begin{array}{l}\text { CYP2D6 } \\
\text { inhibitor }\end{array}$ & 0.003 & \multicolumn{2}{|r|}{$\begin{array}{l}\text { Category 1: Inhibitor; Category 0: Non-inhibitor; } \\
\text { The output value is the probability of being inhibitor. }\end{array}$} \\
\hline $\begin{array}{l}\text { CYP2D6 } \\
\text { substrate }\end{array}$ & 0.107 & \multicolumn{2}{|c|}{$\begin{array}{l}\text { Category 1: Substrate; Category 0: Non-substrate; } \\
\text { The output value is the probability of being substrate. }\end{array}$} \\
\hline $\begin{array}{l}\text { CYP3A4 } \\
\text { inhibitor }\end{array}$ & 0.719 & \multicolumn{2}{|c|}{$\begin{array}{l}\text { Category 1: Inhibitor; Category } 0 \text { : Non-inhibitor; } \\
\text { The output value is the probability of being inhibitor. }\end{array}$} \\
\hline $\begin{array}{l}\text { CYP3A4 } \\
\text { substrate }\end{array}$ & 0.857 & \multicolumn{2}{|r|}{$\begin{array}{l}\text { Category 1: Substrate; Category 0: Non-substrate; } \\
\text { The output value is the probability of being substrate. }\end{array}$} \\
\hline \multicolumn{4}{|l|}{ 6. Excretion } \\
\hline Property & Value & \multicolumn{2}{|c|}{ Comment } \\
\hline CL & 1.748 & \multicolumn{2}{|r|}{ Clearance $\mathrm{n}$ High: $>15 \mathrm{~mL} / \mathrm{min} / \mathrm{kg}$; moderate: $5-15 \mathrm{~mL} / \mathrm{min} / \mathrm{kg}$; low: $<5 \mathrm{~mL} / \mathrm{min} / \mathrm{kg}$} \\
\hline T1/2 & 0.016 & \multicolumn{2}{|r|}{$\begin{array}{l}\text { Category 1: long half-life; Category } 0 \text { : short half-life; long half-life: }>3 \mathrm{~h} \text {; short half-life: }<3 \mathrm{~h} \\
\text { The output value is the probability of having long half-life. }\end{array}$} \\
\hline \multicolumn{4}{|l|}{ 7. Toxicity } \\
\hline Property & Value & \multicolumn{2}{|c|}{ Comment } \\
\hline hERG Blockers & 0.03 & \multicolumn{2}{|r|}{ Category 1: active; Category 0 : inactive; The output value is the probability of being active. } \\
\hline H-HT & 0.342 & \multicolumn{2}{|r|}{$\begin{array}{l}\text { Human Hepatotoxicity Category } 1 \text { : H-HT positive }(+) \text {; Category } 0 \text { : H-HT negative }(-) \text {; The } \\
\text { output value is the probability of being toxic. }\end{array}$} \\
\hline DILI & 0.32 & \multicolumn{2}{|r|}{$\begin{array}{l}\text { Drug Induced Liver Injury. Category 1: drugs with a high risk of DILI; Category 0: drugs with } \\
\text { no risk of DILI. The output value is the probability of being toxic. }\end{array}$} \\
\hline AMES Toxicity & 0.844 & \multicolumn{2}{|r|}{$\begin{array}{l}\text { Category 1: Ames positive }(+) \text {; Category } 0 \text { : Ames negative }(-) \text {; The output value is the } \\
\text { probability of being toxic. }\end{array}$} \\
\hline $\begin{array}{l}\text { Rat Oral Acute } \\
\text { Toxicity }\end{array}$ & 0.978 & \multicolumn{2}{|r|}{$\begin{array}{l}\text { Category } 0 \text { : low-toxicity; Category 1: high-toxicity; The output value is the probability of } \\
\text { being highly toxic. }\end{array}$} \\
\hline FDAMDD & 0.961 & \multicolumn{2}{|r|}{$\begin{array}{l}\text { Maximum Recommended Daily Dose Category 1: FDAMDD (+); Category 0: FDAMDD (-) The } \\
\text { output value is the probability of being positive }\end{array}$} \\
\hline $\begin{array}{l}\text { Skin Sensiti } \\
\text { zation }\end{array}$ & 0.005 & \multicolumn{2}{|r|}{$\begin{array}{l}\text { Category 1: Sensitizer; Category } 0 \text { : Non-sensitizer; The output value is the probability of } \\
\text { being sensitizer. }\end{array}$} \\
\hline
\end{tabular}




\begin{tabular}{|c|c|c|c|}
\hline Carcinogen city & 0.976 & \multicolumn{2}{|c|}{$\begin{array}{l}\text { Category 1: carcinogens; Category 0: non-carcinogens; The output value is the probability of } \\
\text { being toxic. }\end{array}$} \\
\hline Eye Corrosion & 0.003 & \multicolumn{2}{|c|}{$\begin{array}{l}\text { Category 1: corrosives; Category } 0 \text { : non-corrosives The output value is the probability of } \\
\text { being corrosives. }\end{array}$} \\
\hline Eye Irritation & 0.01 & \multicolumn{2}{|c|}{$\begin{array}{l}\text { Category 1: irritants; Category 0: non-irritant The output value is the probability of being } \\
\text { irritants. }\end{array}$} \\
\hline $\begin{array}{l}\text { Respiratory } \\
\text { Toxicity }\end{array}$ & 0.963 & \multicolumn{2}{|c|}{$\begin{array}{l}\text { Category 1: respiratory toxicants; Category } 0 \text { : respiratory non-toxicants The output value is } \\
\text { the probability of being toxic. }\end{array}$} \\
\hline \multicolumn{4}{|c|}{ 8. Environmental toxicity } \\
\hline Property & Value & \multicolumn{2}{|l|}{ Comment } \\
\hline $\begin{array}{l}\text { Bioconcentratio } \\
\text { n Factors }\end{array}$ & 0.985 & \multicolumn{2}{|c|}{$\begin{array}{l}\text { Bioconcentration factors are used for considering secondary poisoning potential and } \\
\text { assessing risks to human health via the food chain. The unit is }-\log 10\left[(\mathrm{mg} / \mathrm{L}) /\left(1000^{*} \mathrm{MW}\right)\right]\end{array}$} \\
\hline IGC $_{50}$ & 3.752 & \multicolumn{2}{|c|}{$\begin{array}{l}\text { Tetrahymena pyriformis } 50 \text { percent growth inhibition concentration The unit is - } \\
\log 10\left[(\mathrm{mg} / \mathrm{L}) /\left(1000^{*} \mathrm{MW}\right)\right]\end{array}$} \\
\hline LC50FM & 5.88 & \multicolumn{2}{|c|}{$\begin{array}{l}\text { 96-hour fathead minnow } 50 \text { percent lethal concentration The unit is - } \\
\log 10\left[(\mathrm{mg} / \mathrm{L}) /\left(1000^{*} \mathrm{MW}\right)\right]\end{array}$} \\
\hline LC50DM & 5.549 & \multicolumn{2}{|c|}{$\begin{array}{l}\text { 48-hour daphnia magna } 50 \text { percent lethal concentration The unit is - } \\
\log 10\left[(\mathrm{mg} / \mathrm{L}) /\left(1000^{*} \mathrm{MW}\right)\right]\end{array}$} \\
\hline \multicolumn{4}{|l|}{ 9. Tox21 pathway } \\
\hline Property & Value & \multicolumn{2}{|l|}{ Comment } \\
\hline NR-AR & 0.022 & \multicolumn{2}{|c|}{$\begin{array}{l}\text { Androgen receptor Category 1: actives; Category 0: inactives; The output value is the } \\
\text { probability of being active. }\end{array}$} \\
\hline NR-AR-LBD & 0.816 & \multicolumn{2}{|c|}{$\begin{array}{l}\text { Androgen receptor ligand-binding domain Category 1: actives; Category } 0 \text { : inactives; Output } \\
\text { value is probability of being active. }\end{array}$} \\
\hline NR-AhR & 0.014 & \multicolumn{2}{|c|}{$\begin{array}{l}\text { Aryl hydrocarbon receptor Category 1: actives; Category } 0 \text { : inactives; The output value is the } \\
\text { probability of being active. }\end{array}$} \\
\hline NR-Aromatase & 0.773 & \multicolumn{2}{|c|}{ Category 1: actives; Category 0: inactives; The output value is the probability of being active. } \\
\hline NR-ER & 0.209 & \multicolumn{2}{|c|}{$\begin{array}{l}\text { Estrogen receptor Category 1: actives; Category 0: inactives; The output value is the } \\
\text { probability of being active. }\end{array}$} \\
\hline NR-ER-LBD & 0.778 & \multicolumn{2}{|c|}{$\begin{array}{l}\text { Estrogen receptor ligand-binding domain Category 1: actives; Category } 0 \text { : inactives; The } \\
\text { output value is the probability of being active. }\end{array}$} \\
\hline $\begin{array}{l}\text { NR-PPAR- } \\
\text { gamma }\end{array}$ & 0.923 & \multicolumn{2}{|c|}{$\begin{array}{l}\text { Peroxisome proliferator-activated receptor gamma Category } 1 \text { : actives; Category } 0 \text { : } \\
\text { inactives; The output value is the probability of being active. }\end{array}$} \\
\hline SR-ARE & 0.711 & \multicolumn{2}{|c|}{$\begin{array}{l}\text { Antioxidant response element Category } 1 \text { : actives; Category } 0 \text { : inactives; The output value is } \\
\text { the probability of being active. }\end{array}$} \\
\hline SR-ATAD5 & 0.976 & \multicolumn{2}{|c|}{$\begin{array}{l}\text { ATPase family AAA domain-containing protein } 5 \text { Category 1: actives; Category 0: inactives; } \\
\text { The output value is the probability of being active. }\end{array}$} \\
\hline SR-HSE & 0.769 & \multicolumn{2}{|c|}{$\begin{array}{l}\text { Heat shock factor response element Category 1: actives; Category 0: inactives; The output } \\
\text { value is the probability of being active. }\end{array}$} \\
\hline SR-MMP & 0.968 & \multicolumn{2}{|c|}{$\begin{array}{l}\text { Mitochondrial membrane potential Category } 1 \text { : actives; Category } 0 \text { : inactives; The output } \\
\text { value is the probability of being active. }\end{array}$} \\
\hline SR-p53 & 0.999 & \multicolumn{2}{|c|}{ Category 1: actives; Category 0: inactives; The output value is the probability of being active. } \\
\hline \multicolumn{4}{|c|}{ 10. Toxicophore Rules } \\
\hline \multicolumn{2}{|l|}{ Property } & Value & Comment \\
\hline \multicolumn{2}{|c|}{ Acute Toxicity Rule } & 0 alerts & 20 substructures; acute toxicity - oral administration \\
\hline \multicolumn{2}{|c|}{ Genotoxic Carcinogenicity Rule } & 8 alerts & 117 substructures; carcinogenicity or mutagenicity \\
\hline \multicolumn{2}{|c|}{$\begin{array}{l}\text { Non-Genotoxic Carcinogenicity } \\
\text { Rule }\end{array}$} & 1 alerts & 23 substructures; carcinogenicity through non-genotoxic mechanisms \\
\hline \multicolumn{2}{|c|}{ Skin Sensitization Rule } & 5 alerts & 155 substructures; skin irritation \\
\hline
\end{tabular}




\begin{tabular}{|l|c|l|}
\hline Aquatic Toxicity Rule & 7 alerts & 99 substructures ; toxicity to liquid(water) \\
\hline Non-Biodegradable Rule & 2 alerts & 19 substructures; non-biodegradable \\
\hline SureChEMBL Rule & 2 alerts & 164 substructures; Med-Chem unfriendly status \\
\hline
\end{tabular}

Table 2 Summary of Physicochemical, Druggability, ADMET of AZA

\begin{tabular}{|c|c|c|}
\hline \multicolumn{2}{|l|}{ PROPERTY } & VALUE \\
\hline \multicolumn{2}{|l|}{ Physicochemical Properties } & \\
\hline \multicolumn{2}{|l|}{ Molecular weight } & $720.72 \mathrm{~g} / \mathrm{mol}$ \\
\hline \multicolumn{2}{|l|}{$\log P$} & -0.20 \\
\hline \multicolumn{2}{|l|}{ LogD } & 0.14 \\
\hline \multicolumn{2}{|l|}{ LogSw } & -4.34 \\
\hline \multicolumn{2}{|l|}{ Number of stereo-centers } & 16 \\
\hline \multicolumn{2}{|l|}{ Stereochemical complexity } & 0.457 \\
\hline \multicolumn{2}{|l|}{ Fsp3 } & 0.771 \\
\hline \multicolumn{2}{|l|}{ Topological polar surface area } & $215.34 \AA^{2}$ \\
\hline \multicolumn{2}{|l|}{ Number of hydrogen bond donors } & 3 \\
\hline \multicolumn{2}{|c|}{ Number of hydrogen bond acceptors } & 16 \\
\hline \multicolumn{2}{|c|}{ Number of smallest set of smallest rings (SSSR) } & 2 \\
\hline \multicolumn{2}{|l|}{ Size of the biggest system ring } & 15 \\
\hline \multicolumn{2}{|l|}{ Number of rotatable bonds } & 6 \\
\hline \multicolumn{2}{|l|}{ Number of rigid bonds } & 38 \\
\hline \multicolumn{2}{|l|}{ Number of charged groups } & $\mathbf{0}$ \\
\hline \multicolumn{2}{|l|}{ Total charge of the compound } & $\mathbf{0}$ \\
\hline \multicolumn{2}{|l|}{ Number of carbon atoms } & 35 \\
\hline \multicolumn{2}{|l|}{ Number of heteroatoms } & 16 \\
\hline \multicolumn{2}{|l|}{ Number of heavy atoms } & 51 \\
\hline \multicolumn{2}{|c|}{ Ratio between The number of non-carbon atoms and the number of carbon atoms } & 0.46 \\
\hline \multicolumn{3}{|l|}{ Druggability Properties } \\
\hline \multicolumn{2}{|l|}{ Lipinski's rule of 5 violations } & 2 \\
\hline \multicolumn{2}{|l|}{ Veber rule } & Low \\
\hline \multicolumn{2}{|l|}{ Egan rule } & Low \\
\hline \multicolumn{2}{|c|}{ Oral PhysChem score (Traffic Lights) } & 5 \\
\hline \multicolumn{2}{|l|}{ GSK's 4/400 score } & Good \\
\hline \multicolumn{2}{|l|}{ Pfizer's 3/75 score } & Good \\
\hline \multicolumn{2}{|c|}{ Weighted quantitative estimate of drug-likeness (QEDw) score } & 0.164 \\
\hline Solubility & & 9441.49 \\
\hline Solubility Forecast Index & & Good \\
\hline ADMET Properties & & \\
\hline Property & Value & Probability \\
\hline Human Intestinal Absorption & $\mathrm{HIA}+$ & 0.890 \\
\hline Blood Brain Barrier & BBB- & 0.773 \\
\hline
\end{tabular}




\begin{tabular}{|c|c|c|}
\hline Caco-2 permeable & Caco2- & 0.711 \\
\hline P-glycoprotein substrate & Substrate & 0.835 \\
\hline P-glycoprotein inhibitor I & Inhibitor & 0.672 \\
\hline P-glycoprotein inhibitor II & Non-inhibitor & 0.534 \\
\hline CYP450 2C9 substrate & Non-substrate & 0.857 \\
\hline CYP450 2D6 substrate & Non-substrate & 0.872 \\
\hline CYP450 3A4 substrate & Substrate & 0.714 \\
\hline CYP450 1A2 inhibitor & Non-inhibitor & 0.887 \\
\hline CYP450 2C9 inhibitor & Non-inhibitor & 0.845 \\
\hline CYP450 2D6 inhibitor & Non-inhibitor & 0.944 \\
\hline CYP450 2C19 inhibitor & Non-inhibitor & 0.833 \\
\hline CYP450 3A4 inhibitor & Non-inhibitor & 0.770 \\
\hline CYP450 inhibitory promiscuity & Low CYP Inhibitory Promiscuity & 0.886 \\
\hline Ames test & Non AMES toxic & 0.756 \\
\hline Carcinogenicity & Non-carcinogens & 0.946 \\
\hline Biodegradation & Not ready biodegradable & 1.000 \\
\hline Rat acute toxicity & 4.348 LD50, mol/kg & PNA \\
\hline hERG inhibition (predictor I) & Weak inhibitor & 0.992 \\
\hline hERG inhibition (predictor II) & Non-inhibitor & 0.569 \\
\hline
\end{tabular}

The physicochemical properties were computed using FAF-Drugs4 (28961788) and RDKit open-source cheminformatics platform. The druggabiity scoring schemes were computed using FAF-Drugs4 (28961788) and FAF-QED (28961788) open-source cheminformatics platform. ADMET features were predicted using admetSAR (23092397) open-source tool.

Table 3 Molecular Properties and of Bioactivity Score of AZA

\begin{tabular}{|c|c|}
\hline Property & Score \\
\hline miLogP & 1.42 \\
\hline TPSA & 215 \\
\hline n-atoms & 51 \\
\hline MW & 721 \\
\hline $\mathrm{n}-\mathrm{ON}$ & 16 \\
\hline n-OHNH & 3 \\
\hline n-violations & 2 \\
\hline n-rotb & 10 \\
\hline Volume & 612 \\
\hline Bioactivity & Score \\
\hline GPCR ligand & -0.71 \\
\hline Ion channel modulator & -1.51 \\
\hline Kinase inhibitor & -1.46 \\
\hline Nuclear receptor ligand & -0.67 \\
\hline Protease inhibitor & -0.35 \\
\hline Enzyme inhibitor & -0.71 \\
\hline
\end{tabular}


Table 4 Swiss Target Prediction

\begin{tabular}{|c|c|c|c|c|c|c|}
\hline Target & $\begin{array}{l}\text { Common } \\
\text { name }\end{array}$ & $\begin{array}{l}\text { Unipro } \\
\text { t ID }\end{array}$ & $\begin{array}{l}\text { ChEMBL } \\
\text { ID }\end{array}$ & Target Class & $\begin{array}{l}\text { Probabi } \\
\text { lity* }\end{array}$ & $\begin{array}{c}\text { Known actives } \\
\text { (3D/2D) }\end{array}$ \\
\hline $\begin{array}{l}\text { Macrophage migration } \\
\text { inhibitory factor }\end{array}$ & MIF & P14174 & $\begin{array}{l}\text { CHEMBL } \\
2085\end{array}$ & Enzyme & 0.06613 & $0 / 1$ \\
\hline $\begin{array}{l}\text { Heat shock protein HSP 90- } \\
\text { alpha }\end{array}$ & HSP90AA1 & P07900 & $\begin{array}{l}\text { CHEMBL } \\
3880\end{array}$ & Other cytosolic protein & 0.06613 & $0 / 2$ \\
\hline Kappa Opioid receptor & OPRK1 & P41145 & $\begin{array}{l}\text { CHEMBL } \\
237\end{array}$ & $\begin{array}{l}\text { Family A G protein- } \\
\text { coupled receptor }\end{array}$ & 0.00 & $0 / 128$ \\
\hline Mu opioid receptor & OPRM1 & P35372 & $\begin{array}{l}\text { CHEMBL } \\
233\end{array}$ & $\begin{array}{l}\text { Family A G protein- } \\
\text { coupled receptor }\end{array}$ & 0.00 & $0 / 35$ \\
\hline Delta opioid receptor & OPRD1 & P41143 & $\begin{array}{l}\text { CHEMBL } \\
236\end{array}$ & $\begin{array}{l}\text { Family A G protein- } \\
\text { coupled receptor }\end{array}$ & 0.00 & $0 / 21$ \\
\hline Thrombin & $\mathrm{F} 2$ & P00734 & $\begin{array}{l}\text { CHEMBL } \\
204\end{array}$ & Protease & 0.00 & $0 / 2$ \\
\hline $\begin{array}{l}\text { Squalene synthetase (by } \\
\text { homology) }\end{array}$ & FDFT1 & P37268 & $\begin{array}{l}\text { CHEMBL } \\
3338\end{array}$ & Enzyme & 0.00 & $0 / 28$ \\
\hline $\begin{array}{l}\text { Glycogen synthase kinase- } \\
3 \text { beta }\end{array}$ & GSK3B & P49841 & $\begin{array}{l}\text { CHEMBL } \\
262\end{array}$ & Kinase & 0.00 & $0 / 1$ \\
\hline $\begin{array}{l}\text { Glycogen synthase kinase- } \\
3 \text { alpha }\end{array}$ & GSK3A & P49840 & $\begin{array}{l}\text { CHEMBL } \\
2850\end{array}$ & Kinase & 0.00 & $0 / 1$ \\
\hline Protein kinase $\mathrm{C}$ alpha & PRKCA & P17252 & $\begin{array}{l}\text { CHEMBL } \\
299\end{array}$ & Kinase & 0.00 & $0 / 1$ \\
\hline Apoptosis regulator $\mathrm{Bcl}-\mathrm{X}$ & BCL2L1 & $\begin{array}{l}\text { Q0781 } \\
7\end{array}$ & $\begin{array}{l}\text { CHEMBL } \\
4625\end{array}$ & Other ion channel & 0.00 & $0 / 1$ \\
\hline HMG-CoA reductase & HMGCR & P04035 & $\begin{array}{l}\text { CHEMBL } \\
402\end{array}$ & Oxidoreductase & 0.00 & $0 / 1$ \\
\hline Zinc finger protein GLI1 & GLI1 & P08151 & $\begin{array}{l}\text { CHEMBL } \\
5461\end{array}$ & Transcription factor & 0.00 & $0 / 1$ \\
\hline Proto-oncogene c-JUN & JUN & P05412 & $\begin{array}{l}\text { CHEMBL } \\
4977\end{array}$ & Transcription factor & 0.00 & $0 / 2$ \\
\hline $\begin{array}{l}\text { Vanilloid receptor (by } \\
\text { homology) }\end{array}$ & TRPV1 & $\begin{array}{l}\text { Q8NER } \\
1\end{array}$ & $\begin{array}{l}\text { CHEMBL } \\
4794\end{array}$ & $\begin{array}{l}\text { Voltage-gated ion } \\
\text { channel }\end{array}$ & 0.00 & $0 / 1$ \\
\hline
\end{tabular}

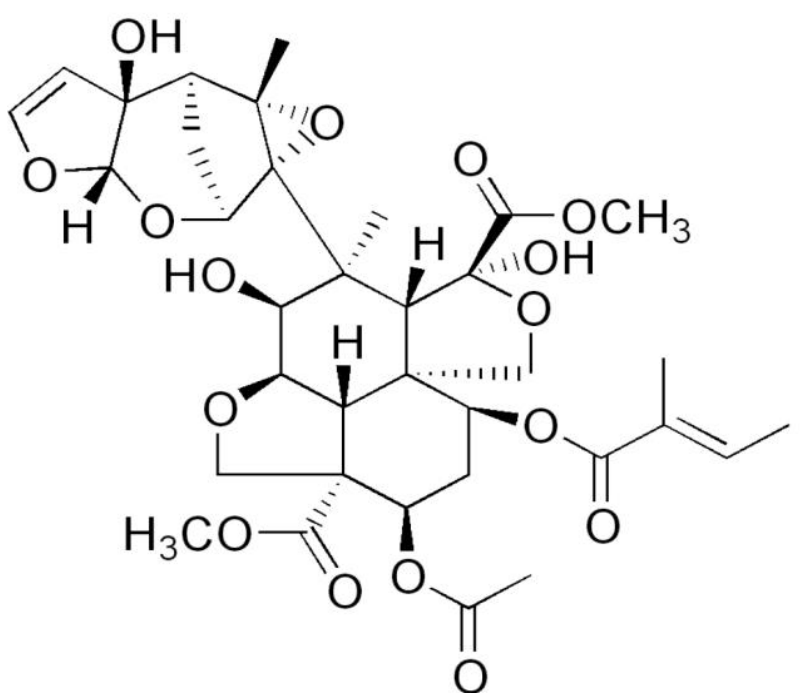

Figure 1: Structure of Azadirachtin (AZA) molecule 
A)

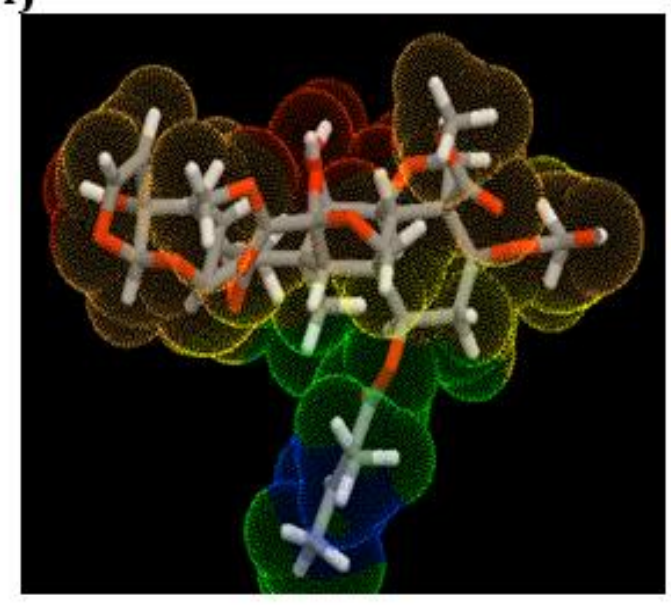

C)

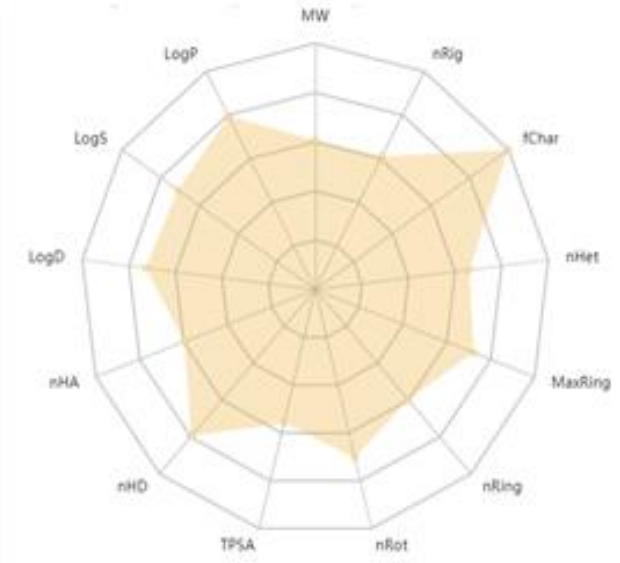

E)

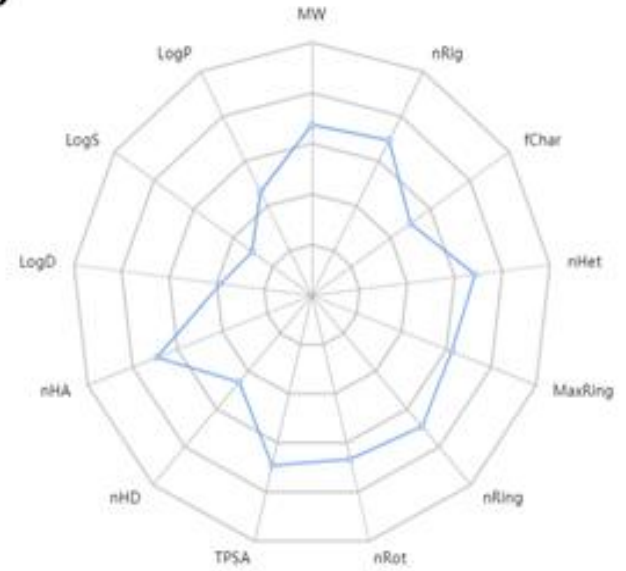

B)

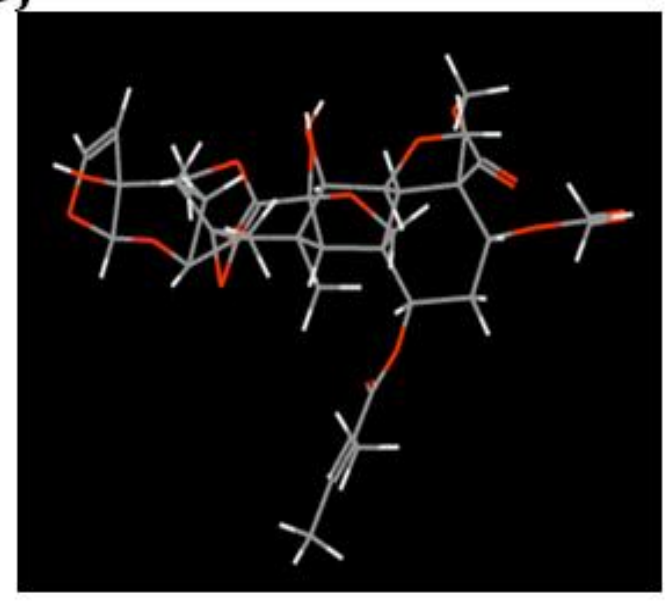

D)

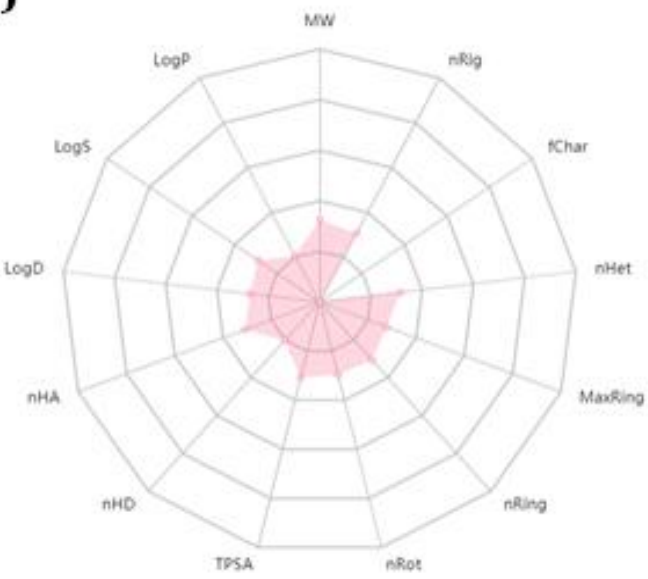

F)

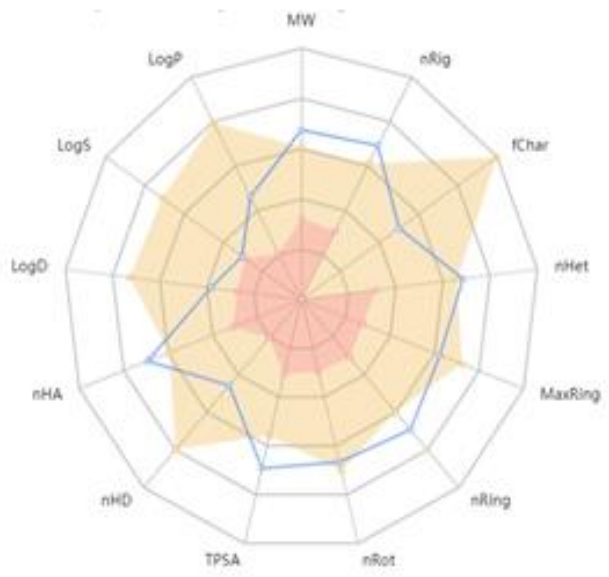

Figure 2: Phytocompound physiochemical properties of Azadirachtin; a) 3D; b) 2D; c) Upper Limit Radar Map; d) Lower Limit Radar Map; e) Compound Properties Radar Map; f) Cumulative Radar Map. 


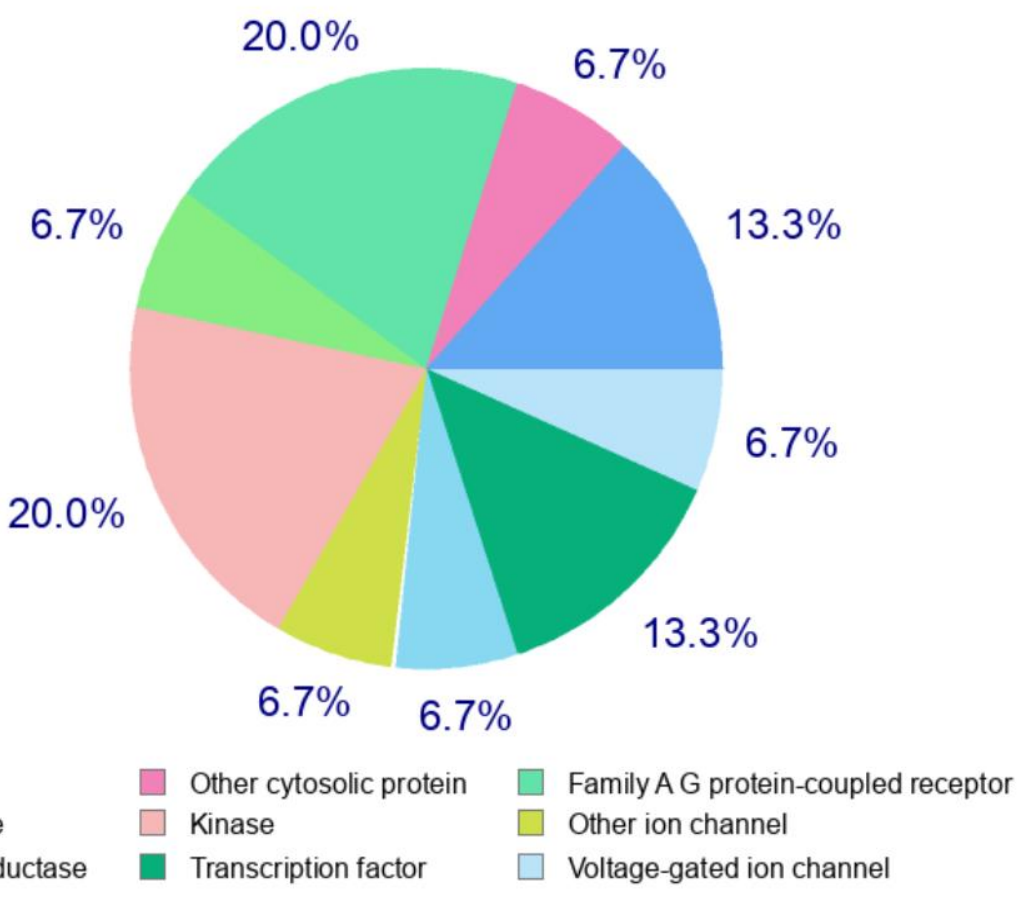

Figure 3: Bioactivity properties and percentage distribution chart for Azadirachtin

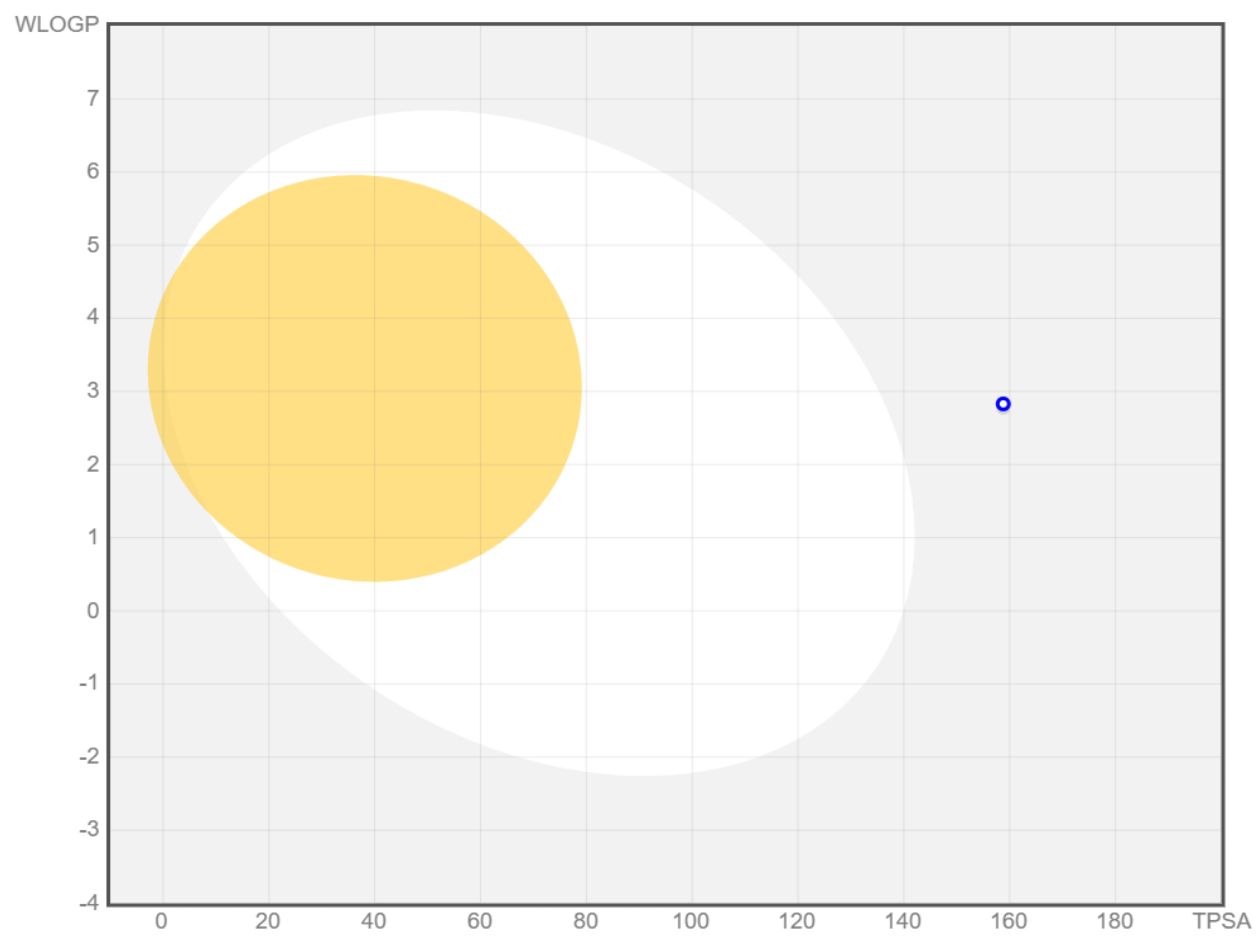

Figure 4: Boiled Egg Model for Azadirachtin as drug candidate 